Jurnal Psikologi Pendidikan \& Konseling

Volume 3 Number 2 December 2017. Page 46-54

p-ISSN: 2443-2202 e-ISSN: 2477-2518

Homepage: http://ojs.unm.ac.id/index.php/JPPK

\title{
Keterampilan Metakognisi Mahasiswa Program Studi Bimbingan Dan Konseling Terhadap Mata Kuliah Statistik
}

\author{
Muya Barida \\ Bimbingan dan Konseling, Universitas Ahmad Dahlan \\ Email: muya.barida@bk.uad.ac.id
}

(Diterima: 07-Agustus-2017; direvisi: 18-Oktober-2017; dipublikasikan: 27-Desember-2017)

\begin{abstract}
The purpose of this study to determine metacognition skills possessed by students. The study used phenomenology research model. Subjects of this study are counseling and guidance students who follow the statistical course of the 2010-2014 class. Data were collected by conducting interviews and through qualitative questionnaires. Further data is analyzed by phenomenology analysis technique. The result of the study can be concluded that the student tendency has negative metacognition skills and some students have positive metacognition skills.
\end{abstract}

Keywords: Metacognition skills; statistics; students.

\begin{abstract}
Abstrak. Tujuan studi ini untuk mengetahui keterampilan metakognisi yang dimiliki oleh mahasiswa. Studi menggunakan model penelitian fenomenologi. Subjek studi ini adalah mahasiswa bimbingan dan konseling yang mengikuti matakuliah statistik dari angkatan 2010-2014. Data dikumpulkan dengan melaksanakan kegiatan wawancara dan melalui kuesioner kualitatif. Selanjutnya data dianalisis dengan teknik analisis fenomenologi. Hasil dari studi dapat disimpulkan bahwa kecenderungan mahasiswa memiliki keterampilan metakognisi yang negatif dan beberapa mahasiswa ada yang memiliki keterampilan metakognisi yang positif.
\end{abstract}

Kata Kunci: Keterampilan metakognisi; statistik; mahasiswa.

Copyright $(9) 2017$ Universitas Negeri Makassar. This is an open access article under the CC BYNC-ND license (http://creativecommons.org/licenses/by-nc-nd/4.0/).

\section{PENDAHULUAN}

Kognisi yang biasa dikenal sebagai kehidupan, aktivitas atau proses mental yang terjadi di dalam otak merupakan salah satu aspek yang mendorong terjadinya perilaku individu. Wade \& Tavris (2007: 272-273) berasumsi bahwa proses mental yang didalamnya meliputi perolehan informasi, membuat keputusan, menalar, dan menjawab suatu masalah akan mempengaruhi apa yang dilakukan individu. Selain itu, proses mental juga mempengaruhi sifat-sifat kepribadian yang individu kembangkan. Setiap peserta didik yang mengalami suatu pengalaman yang sama, bisa saja akan memperoleh pembelajaran dan menunjukkan perilaku yang berbeda dikarenakan oleh proses mental atau kognisi.

Teori Gestalt (dalam Hergenhahn \& Olson, 2008) menggambarkan mekanisme munculnya perilaku yang dimulai dari adanya stimulasi eksternal (sensoris, bersifat indrawi) menimbulkan reaksi di otak. Kemudian otak aktif mengubah stimulasi sensoris. Selanjutnya 
otak akan mengorganisasikan, menyederhanakan, dan memberi makna pada informasi sensoris. Ekspresi atau respon akurat dari suatu situasi di otak ini berasal dari kekuatan medan yang ada di dalam otak berupa dunia fenomenal atau kesadaran. Informasi sensoris yang telah ditransformasikan oleh kekuatan medan di otak itu dialami secara sadar, sehingga individu akan memaknai suatu fenomena yang bersifat sensoris apabila dalam keadaan sadar. Hal ini sesuai hukum Pregnanz bahwa manusia merespon dunia sedemikian rupa untuk membuat dunia menjadi bermakna dalam kondisi yang ada. Pada akhirnya, kekuatan medan yang memunculkan pengalaman yang bermakna dan tertata akan diekspresikan dalam bentuk perilaku.

Penjelasan di atas sesuai dengan Franz

From (dalam Boeree, 2008: 107) yang mengemukakan bahwa manusia mengalami perilaku sebagai hal yang dikendalikan oleh sebuah faktor mental. Pendapat From yang mengnanut aliran psikologi kognitif ini dengan jelas menyatakan bahwa proses mental atau kognisi mendorong terjadinya perilaku individu. Lebih lanjut, jika dilihat dari sudut pandang neuroscience, Boeree (2008: 21-23) menjelaskan bahwa kehidupan mental di otak mencakup aktivitas-aktivitas sistem saraf. Sistem saraf tersusun atas miliaran sel, dan yang paling esensial dinamakan sel saraf atau neuron. Setiap neuron memiliki perpanjanganperpanjangan yang disebut dendrit. Namun ada satu perpanjangan yang berbeda, yang disebut akson. Fungsi akson ini adalah mentransmisikan sinyal elektrokimia ke neuron lain. Ketika sinyal elektrokimia ini bergerak di sepanjang akson akan diubah menjadi suatu pesan kimiawi yang berjalan ke neuron selanjutnya. Pada saat ini, unsur kimiawi menyentuh permukaan neuron dan akan mengubah keseimbangan ion-ion antara bagian dalam dan luar selaput sel. Ketika perubahan ini mencapai level ambang, maka dampaknya bergerak melintasi membran sel menuju akson. Ketika mencapai akson, maka akan memacu mulainya potensi perilaku.

Berdasarkan mekanisme munculnya perilaku di atas, dapat dijelaskan bahwa perilaku manusia dipengaruhi oleh cara berpikir dalam memproses informasi. Ketika suatu keadaan lingkungan sebagai stimulasi sensoris yang diulang-ulang, bisa saja memunculkan perilaku yang berulang-ulang karena manusia menggunakan mekanisme pikiran yang sama.
Hal ini juga berlaku pada mahasiswa dalam kaitannya dengan mata kuliah yang mereka tempuh, salah satunya mata kuliah statistik.

Mahasiswa yang mempunyai mekanisme pikiran sama secara berulang-ulang, akan memunculkan perilaku yang sama pula dari kebiasaannya. Mahasiswa menunjukkan suatu perilaku berupa kegiatan belajar, keaktifan bertanya di kelas, diskusi dengan teman dapat dipengaruhi oleh cara berpikirnya terhadap suatu mata kuliah. Oleh karena itu, hendaknya mahasiswa memperlakukan cara berpikirnya secara baik untuk menunjukkan suatu perilaku yang positif pula.

Perlakuan terhadap proses kognisi ini dikenal sebagai metakognisi (Flavell, 1979). Berdasarkan penjelasan yang sudah dikemukanan di atas, maka mahasiswa sangat perlu menguasai metakognisi. Hal tersebut sesuai dengan pernyataan Holder et al. (dalam Wilkinson, 2011) bahwa individu dengan keterampilan metakognisi yang berkembang dengan baik menunjukkan kemampuan untuk melakukan monitoring diri dan mengarahkan perilaku diri. Mahasiswa yang mampu mengembangkan keterampilan metakognisinya, akan mampu melakukan monitoring dan mengarahkan diri untuk menguasai materi mata kuliah statistik.

Metakognisi adalah pengetahuan individu mengenai kognisinya dan kemampuan untuk mengontrol dengan mengorganisasikan, memonitoring, dan memodifikasinya sebagai fungsi dari pembelajaran. Metakognisi merupakan aspek yang penting dari pembelajaran individu. Hal ini mencakup regulasi diri, refleksi terhadap kekuatan, kelemahan kinerja diri, dan strategi pembelajaran (EPSI, 2005). Berdasarkan pernyataan ini, metakognisi memegang peran yang sangat penting dalam aktivitas pembelajaran mahasiswa dalam mengikuti perkuliahan mata kuliah statistik. Melalui kegiatan pengaturan diri, refleksi terhadap kelemahan dan kekuatan atas apa yang telah dilakukan serta strategi pembelajaran yang telah diupayakan, maka mahasiswa akan mampu meningkatkan kualitas proses maupun hasil belajar.

Mahasiswa yang mampu memanajemen metakognisi dengan baik, mampu menunjukkan performa belajar yang baik pula. Jones (2003: 12) mengemukakan bagaimana individu mampu memanajemen metakognisi sehingga dapat 
mempengaruhi komunikasi mereka. Kemampuan tersebut antara lain: (a) individu dapat memahami bahwa mereka mempunyai pikiran dengan kapasitas untuk berpikir luar biasa secara sadar yang dapat mereka kembangkan; (b) individu dapat lebih efisien dalam berpikir tentang pikiran mereka jika mereka memandang proses mental yang mereka miliki merupakan keterampilan-keterampilan yang dapat mereka latih; dan (c) pada kehidupan sehari-hari, individu dapat mempraktikkan dengan tekun menggunakan keterampilan pikiran untuk mempengaruhi komunikasi mereka. Berdasarkan pendapat tersebut, dapat disimpulkan bahwa melalui manajemen metakognisi maka mahasiswa mampu menyadari bahwa mereka mempunyai potensi untuk memproduksi pikiran-pikiran yang luar biasa, mampu melatih keterampilan berpikir sehingga lebih efisien, dan mampu memproduksi kegiatan belajar dengan performa maksimal dalam mempelajari materi mata kuliah statistik.

Penelitian juga dilakukan oleh Anderson (2002) yang menyatakan bahwa keterampilan metakognisi perlu dimiliki oleh guru bahasa juga pebelajar, dalam penyelenggaraan kegiatan belajar dan pembelajaran. Ketika mereka merefleksikan strategi belajar dan pembelajaran mereka, maka mereka akan lebih siap untuk membuat keputusan tentang apa yang dapat mereka lakukan untuk meningkatkan kegiatan belajar dan pembelajaran. Apabila mahasiswa memiliki keterampilan metakognisi, mereka akan senantiasa merefleksikan strategi belajar yang mereka lakukan dalam mempelajari materi mata kuliah statistik sehingga mereka lebih siap mengikuti pembelajaran.

Concepcion (2004), menyampaikan bahwa dengan membuat pengajaran lebih sadar secara metakognisi maka pengajar mampu meningkatkan hasil belajar siswa. Lebih khusus lagi pengajaran yang diinformasikan secara metakognitif yang secara eksplisit mendiskusikan latar belakang informasi relevan, dapat membantu siswa-siswa filsafat untuk lebih mengembangkan keterampilan penting dalam membaca dan melakukan filsafat dengan baik. Apabila mahasiswa mampu menggunakan metakognisinya secara tepat, maka mereka mampu mengembangkan keterampilan dari materi mata kuliah statistik yang dipelajari.

Sementara Maulana (2008) meneliti penggunaan pendekatan metakognitif dalam pembelajaran terhadap mahasiswa dan memperoleh pemahaman bahwa melalui pendekatan metakognitif, keterampilan berpikir kritis mahasiswa meningkat daripada mahasiswa yang diajarkan melalui pendekatan konvensional. Mahasiswa mampu meningkatkan keterampilan berpikir kritis baik bagi mahasiswa yang memiliki prestasi yang tinggi, sedang, maupun rendah, aktivitas mahasiswa semakin berkualitas, dan baik mahasiswa maupun dosen mempunyai sikap positif dan dukungan yang kuat terhadap pembelajaran mata kuliah statistik.

Nordell (2009) juga melakukan penelitian dengan menyelenggarakan workshop strategi belajar melalui pemanfaatan metakognisi terhadap mahasiswa baru. Hasilnya menunjukkan bahwa mahasiswa yang mengikuti workshop mencapai hasil ujian yang lebih baik secara signifikan daripada mahasiswa yang tidak mengikuti workshop. Mahasiswa mampu meningkatkan keterampilan asesmen diri dan keterampilan metakognisi yang diperlukan untuk mengidentifikasi masalah diri terhadap strategi belajar dalam mempelajari materi mata kuliah statistik.

Lebih lanjut, Jayapraba (2013) menyampaikan bahwa ada hubungan yang signifikan antara kesadaran metakognitif dan prestasi. Hasil penelitian membuktikan bahwa keterampilan metakognitif merupakan keterampilan yang paling efektif karena strategis dalam mencapai prestasi akademik. Mytkowicz, et al. (2014) juga melakukan penelitian kepada mahasiswa S1 tentang metakognisi. Hasil penelitian tersebut menujukkan bahwa perubahan skor metakognisi berkorelasi dengan performa akademik ketika diukur dengan Grade Point Average (GPA). Mahasiswa yang mencapai skor metakognisi yang tinggi, juga menunjukkan performa akademik yang tinggi. Semakin tinggi kemampuan self regulated learning, maka IPK yang lebih tinggi akan tercapai (Darmiany, 2015).

Berdasarkan pendapa-pendapat di atas dapat dinyatakan bahwa apabila mahasiswa menggunakan kemampuan metakognisi, maka mereka mampu menunjukkan performa akademik dalam mempelajari mata kuliah statistik secara optimal.

Berbagai penelitian di atas menunjukkan bahwa metakognisi dapat mempengaruhi perilaku individu di dalam kehidupan seharihari, termasuk mahasiswa. Menurut pernyataan 
beberapa mahasiswa, bahwa mata kuliah statistik sangat sulit dan lebih sulit dibandingkan dengan tugas-tugas mata kuliah yang lain. Oleh karena itu, peneliti ingin mengetahui keterampilan metakognisi yang dimiliki oleh mahasiswa Bimbingan dan Konseling Universitas Ahmad Dahlan terhadap mata kuliah statistik.

\section{METODE}

Studi ini menggunakan pendekatan kualitatif dengan model penelitian fenomenologi (Creswell, 2012). Peneliti berusaha untuk mencari hal-hal yang esensial atau arti pengalaman yang mendasar mengenai "statistik" dan menekankan pada intensitas kesadaran (Husserl dalam Cresswell, 2012). Peneliti juga memahami esensi pengalaman dunia terdalam mahasiswa (inner world) tentang suatu fenomena berdasar perspektif mahasiswa terhadap statistik (Hanurawan, 2012: 74). Masing-masing individu mempunyai pengalaman. Namun tidak berarti bahwa dengan pengalaman yang sama perspektifpun akan sama, namun bisa saja setiap individu memiliki perspektif yang berbeda.

Subjek studi ini adalah mahasiswa Bimbingan dan Konseling Universitas Ahmad Dahlan yang mengikuti mata kuliah statistik. Penentuan subjek studi ini menggunakan desain Non-Probability Sampling dengan teknik Purposive Sampling (Leedy \& Ormrod, 2005: 206).

Studi ini menggunakan tiga jenis instrumen, yaitu 1) Pedoman wawancara melalui wawancara terpimpin, 2) Kuesioner kualitatif, dan 3) Pedoman observasi sebagai penguat dari temuan hasil wawancara dan pengisian kuesioner kualitatif.

Prosedur penelitian yang diterapkan dalam studi ini mengacu pada Lincoln \& Guba (dalam Nasution, 1988: 33) yang terdiri dari tiga tahap, antara lain 1) Tahap orientasi, yaitu tahap untuk memperoleh informasi yang dipandang penting untuk ditindaklanjuti, 2) Tahap eksplorasi, yaitu tahap untuk memperoleh informasi secara mendalam mengenai hal-hal yang telah ditentukan untuk dicari keabsahannya, dan 3) Tahap member check, yaitu tahap untuk mengkonfirmasikan bahwa laporan yang diperoleh dari subjek studi sesuai dengan data yang ditampilan subjek studi dengan cara mengoreksi, mengubah, dan memperluas data sehingga menampilkan fenomena yang terpercaya.

Selain itu, peneliti juga menerapkan langkah penelitian yang dikemukakan oleh Creswell (2012) terdiri dari: 1) Epoche, yaitu menangguhkan atau menahan diri dari semua keputusan positif. Peneliti harus memiliki ketajaman atau kecermatan dalam mengamati subjek studi; dan 2) Ideation, yaitu menemukan esensi realitas dari subjek studi. Esensi dari langkah ini meliputi: a) karakteristik umum yang mencakup semua hal-hal yang sejenis, b) universal, yaitu mencakup sejumlah hal-hal yang sejenis, dan c) kondisi yang harus dimiliki oleh hal-hal tertentu untuk dapat digolongkan dalam jenis yang sama.

Studi ini mengadaptasi langkah penelitian di atas, yaitu 1) Tahap orientasi, peneliti menemukan bahwa keterampilan metakognisi mahasiswa terhadap mata kuliah statistik merupakan masalah penting untuk ditelusuri secara mendalam; 2) Tahap eksplorasi dilalui dengan melakukan wawancara kualitatif, kuesioner kualitatif, dan observasi. Pada tahap ini, peneliti juga memegang Epoche; 3) Tahap member check dilakukan dengan menganalisis dan mengevaluasi kebenaran data yang telah diperoleh dari mahasiswa dengan melalui wawancara, kuesioner dan data sekunder. Pada tahap ini peneliti melakukan Ideation.

Data yang dikumpulkan berupa data tentang keterampilan metakognisi mahasiswa yang terdiri dari 14 pernyataan atau pertanyaan. Peneliti memperoleh data dengan cara mengumpulkan data hasil wawancara, hasil pengisian kuesioner kualitatif dan data hasil observasi.

nalisis data dalam studi in dengan teknik analisis fenomenologi. Secara rinci, dijelaskan bahwa tahap-tahap studi menerapkan langkap dari Giorgi \& Giorgi (dalam Hanurawan, 2012: 75) meliputi: 1) Membaca data untuk memahami secara keseluruhan, 2) Menentukan bagian-bagian untuk menetapkan unit-unit yang bermakna, 3) Transformasi unit-unit bermakna ke dalam ekspresi-ekspresi sensitif psikologis, dan 4) Menentukan struktur.

\section{HASIL DAN PEMBAHASAN}

Subjek studi ini adalah mahasiswa Bimbingan dan Konseling yang mengikuti matakuliah statistik. Mahasiswa ini terdiri dari mahasiswa laki-laki dan perempuan dengan 
rentang usia antara 19-24 tahun. Mahasiswa ini terdistribusi mulai angkatan 2010 hingga 2014. Mahasiswa berasal dari berbagai daerah di Indonesia, antara lain: 1) Cirebon, 2) Sungailiat, 3) Cilacap, 4) Klaten, 5) Banjarnegara, 6) Trikoyo, 7) Bandung, 8) Pamenang, 9) Purbalingga, 10) Kebumen, 11) Cilacap, 12) Tapanuli Selatan, 13) Bantul, 14) Kota Agung, 15) Kebumen, 16) Gunung kidul, 17) Yogyakarta, 18) Sleman, 19) Ciamis, 20) Kulonprogo, 21) Bangka, 22) Subang, 23) Sukabumi, 24) Tasikmalaya, 25) Kediri, 26) Purworejo, 27) Lampung, 28) Muara Bulian, 29) Lopok, 30) Indramayu, 31) Bogor dan 32) Muara Enim.

Peneliti menggunakan alat pengumpulan data utama dengan wawancara dan kuesioner kualitatif. Wawancara dilakukan dengan memberikan pertanyaan yang terdiri dari 14 pertanyaan. Selanjutnya kuesioner kualitatif berupa 14 item pernyataan untuk mengetahui keterampilan metakognisi mahasiswa terhadap mata kuliah statistik kepada subjek studi. Selain itu peneliti juga melakukan observasi sebagai pendukung temuan hasil pengumpulan data.

Peneliti membagi tema keterampilan metakognisi menjadi tiga, yaitu merencanakan proses kognisi, mengontrol proses kognisi, dan mengevaluasi proses kognisi. Tema ini dibagi menjadi beberapa sub-tema yaitu 1) Merencanakan proses kognisi, terdiri dari: a) menyadari kemampuan diri dan b) menciptakan aturan main; 2) Mengontrol proses kognisi, terdiri dari a) menciptakan persepsi, b) menciptakan wicara diri, dan c) menciptakan gambar visual; dan 3) Mengevaluasi proses kognisi, terdiri dari a) menciptakan penjelasan dan b) menciptakan pengharapan. Setiap subtema memiliki dua item pertanyaan atau pernyataan yang berguna untuk mengungkap keterampilan metakognisi mahasiswa terhadap mata kuliah statistik. Adapun hasil pengumpulan dan analisis data melalui wawancara dan kuesioner kualitatif dapat diuraikan sebagai berikut.

Pendekatan yang peneliti gunakan melalui fenomenologi bertujuan untuk memperoleh pemahaman dan menggambarkan realitas yang kompleks (Nasution, 2003). Mata kuliah statistik di kalangan mahasiswa merupakan suatu fenomena yaitu mata kuliah ini sering disebut sebagai "momok yang menakutkan". Hasil analisis mengenai keterampilan metakognisi mahasiswa terhadap mata kuliah statistik dapat disampaikan melalui pembahasan di bawah ini.

Pada tema merencakan proses kognisi dengan sub-tema menyadari kemampuan diri, dapat dipahami bahwa 40 mahasiswa menyadari bahwa mereka tidak mempunyai kemampuan di bidang statistik dan merasa sulit dalam mempelajari mata kuliah statistik antara lain dalam menghafal dan menerapkan rumus, sulit berhitung, kurangnya ketelitian, sulit memahami soal dan kurangnya konsentrasi. Di sisi lain, 19 mahasiswa sebenarnya menyadari bahwa mereka mempunyai kemampuan di bidang statistik, namun pada kenyataannya mereka mengakui beberapa kesulitan yang ditemui dalam mata kuliah statistik antara lain sulit menyusun tabel, kurangnya ketelitian, sulit memahami soal, sulit memahami dan menerapkan rumus dan mempelajari hitungan.

Pada tema merencanakan proses kognisi dengan sub-tema menciptakan aturan main, 59 mahasiswa memiliki prinsip untuk mempelajari mata kuliah statistik, mengerjakan soal-soal yang diberikan, dan berusaha untuk menguasai mata kuliah statistik baik itu dengan terus belajar, bertanya kepada teman yang lebih ahli serta tidak malu bertanya kepada dosen sehingga dapat lulus dengan nilai A. Namun ketika prinsip itu dibenturkan dengan suatu tantangan atau kesulitan yang terjadi, sembilan mahasiswa mengalami suatu keputusasaan dan memilih untuk menyerah.

Pada tema mengontrol proses kognisi dengan sub-tema menciptakan persepsi maka dapat dilihat sepuluh mahasiswa memiliki persepsi bahwa statistik itu indah dan menarik, menantang karena melatih ketelitian, mengasah otak dan mengasikkan. Sementara 49 mahasiswa memiliki persepsi bahwa statistik itu rumit, sulit, membuat pusing, merepotkan karena rumus sulit dipahami, dihafalkan, dan diterapkan, memerlukan ketelitian, berkaitan dengan angka, symbol, sulit berhitung.

Pada tema mengontrol proses kognisi dengan sub-tema menciptakan wicara diri, 53 mahasiswa berbicara kepada diri mereka sendiri bahwa pasti bisa menguasai mata kuliah statistik, bersemangat, semua pasti dapat dikuasai dan harus mengingat prinsip awal. Sedangkan enam mahasiswa melakukan wicara diri bahkan apabila berbicara kepada dirinya merasa pesimis, merasa bahwa statistik itu sulit dan rumit. 
Pada tema mengontrol proses kognisi dengan sub-tema menciptakan gambar visual bahwa enam mahasiswa menggambarkan statistik seperti bola yang harus dimainkan dengan kerja keras dan semangat, bunga mawar yang mekar karena menarik dan menantang, bunga di padang pasir yang indah karena ketika dapat menyelesaikan akan merasa bahagia, tekateki yang dapat dipecahkan dengan banyak cara, dan dapat dipelajari. Sementara 53 mahasiswa menggambarkan statistik seperti coretan, benang kusut, jarum di tumpukan jerami, roller coaster, pohon kaktus, benang atau tali yang rusak, kertas tertitup angin, menulis di atas pasir, kado yang mengejutkan, godzila yang menyeramkan, magnet dengan kutub $U$ dan $U$ karena memerlukan ketelitian yang sangat tinggi, berupa rumus dan angka yang sulit dipahami dan dikerjakan, membuat pusing, terdiri dari angka dan rumus yang membuat berputar-putar, sulit dihafalkan dan dipahami rumusnya.

Pada tema mengevaluasi proses kognisi dengan sub-tema menciptakan penjelasan, dapat ditemukan alasan subjek menyadari kemampuan, menciptakan aturan main, memiliki persepsi, melakukan wicara diri dan menggambarkan visual tentang mata kuliah statistik bahwa 30 mahasiswa karena meskipun sulit, rumit, memerlukan kesabaran dan ketelitian, serta menantang namun statistik itu menyenangkan dan harus dipelajari karena berguna untuk kehidupan terutama dalam penyusunan skripsi. Sementara 29 mahasiswa menyatakan bahwa statistik memang sulit dalam menghafalkan rumus, berhitung secara teliti, tidak dapat memahami dan membuat pusing, dan tidak merasa mempunyai bakat berhitung walaupun dipaksa.

Pada tema mengevaluasi proses kognisi dengan sub-tema menciptakan pengharapan, 59 mahasiswa memiliki harapan agar dapat lebih teliti dan cermat, menguasai materi, dapat berhitung, dapat memahami, memilih dan menerapkan rumus dengan benar, dan lulus dengan nilai A serta dapat memanfatkan untuk analisis data skripsi melalui usaha belajar, bertanya kepada teman, berdoa dan memegang prinsip.

Metakognisi yang dimiliki mahasiswa dari aspek merencanakan proses kognisi, mengontrol proses kognisi, dan mengevaluasi proses kognisi sangat berpengaruh terhadap kompetensi kepribadian untuk menghadapi tantangan mata kuliah statistik. Arslan \& Akin
(2014) berpendapat bahwa metakognisi mempengaruhi academic locus of control dalam diri mahasiswa, yang mana mahasiswa yang memiliki internal academic locus of control tinggi cenderung lebih mengadopsi metakognisi daripada mahasiswa yang memiliki external academic locus of control tinggi.

Metakognisi sangat besar pengaruhnya pada kemampuan mahasiswa dalam belajar menguasai materi mata kuliah statistik, yaitu mereka mampu mengontrol kegiatan belajar mereka sendiri, daripada dikontrol oleh lingkungan luar atau orang lain. Pendidikan dapat membelajarkan peserta didik untuk memiliki keterampilan metakognitif ini. Zimmerman (dalam Laskey \& Hetzel, 2010) mengemukakan bahwa metakognisi bukanlah proses otomatis tetapi dapat dilihat sebagai keterampilan yang dapat diajarkan dan bagian dari konsep yang lebih besar dari pembelajaran yang diatur oleh diri sendiri.

Keterampilan metakognitif sangat berguna bagi peserta didik. Shanon (2008) menemukan bahwa mengajarkan peserta didik keterampilan metakognitif merupakan keterampilan yang berguna, yaitu membantu peserta didik menjadi pebelajar yang lebih mampu mengarahkan diri sendiri. Melalui pertanyaan-pertanyaan metakognitif, peserta didik dapat belajar bagaimana mereka belajar dan gaya belajar apa yang mereka miliki, menilai diri dengan selalu mengevaluasi kinerja dan kemajuan mereka dalam belajar, serta mendorong motivasi dari dalam diri mereka sendiri untuk belajar. Hal ini dapat membantu peserta didik mengembangkan keterampilan belajar

Ketika peserta didik menggunakan keterampilan metakognisi, maka proses dan hasil belajar statistik lebih optimal. Pate \& Miller (2011) mendefinisikan metakognisi sebagai keterlibatan secara aktif pada pikiran individu. Individu melakukan proses seleksi, evaluasi, revisi, dan memutuskan tugas-tugas kognitif, tujuan-tujuan, dan strategi-strategi dalam pikirannya sendiri terhadap suatu hal yang berkaitan dengan kemampuan dan minat yang muncul.

Melalui metakognisi yang tepat, peserta didik dapat menunjukkan kinerja yang efektif dan efisien. Peserta didik akan menyadari pembelajaran dalam kehidupan mereka, mengembangkan strategi pembelajaran secara lebih baik, dan terampil untuk menerapkan 
strategi dalam situasi yang baru (Bednarik\& Keinonen, 2011). Scott \& Berman (2013) mengemukakan bahwa persepsi tentang kesulitan dan tingkat minat mempunyai hubungan yang kuat dengan metakognisi. Hal ini menunjukkan bahwa peserta didik yang mempunyai metakognisi yang baik, akan memiliki persepsi yang positif.

Selanjutnya Hamman \& Stevens (1998) mengemukakan bahwa metakognisi berkaitan dengan kinerja peserta didik. Secara lebih khusus, peserta didik menggunakan strategi untuk mempelajari materi statistik dan tipe-tipe motivasi yang mereka miliki. Hal ini berarti membuktikan bahwa kesadaran metakognisi berkaitan dengan motivasi tugas dan strategistrategi yang digunakan berikutnya dalam mempersiapkan asesmen kelas. Peserta didik yang memiliki keterampilan metakognisi yang baik, akan memiliki motivasi yang tinggi sehingga kinerjanya akan lebih berkualitas.

Isaacson \& Fujita (2006) menyatakan bahwa metakognisi berhubungan dengan self regulated learning dan kesuksesan akademik. Peserta didik yang mampu memonitoring pengetahuan metakognitif mereka menunjukkan pencapaian kesuksesan akademik yang tingggi. Pencapaian kesuksesan akademik yang tinggi ini yaitu lebih akurat pada prediksi hasil ujian peserta didik, lebih realistis terhadap tujuantujuan, lebih mampu menyesuaikan kepercayaan diri terhadap hasil ujian, dan lebih efektif dalam memilih pertanyaan ujian yang dapat pebelajar jawab. Penemuan tersebut menunjukkan bahwa metakognisi dapat mempengaruhi kemampuan untuk memprediksi kemampuan peserta didik untuk mencapai tujuan yang realistik, kepercayaan diri, dan mengambil keputusan.

Senada dengan pendapat di atas, Hall \& Webster (2008) juga mengungkapkan manfaat metakognisi. Metakognisi mempengaruhi kemampuan dan pencapaian akademik. Peserta didik yang menggunakan proses metakognisinya secara efektif, menunjukkan kemampuan yang kuat dan pencapaian akademik yang positif. Peserta didik mempunyai inisiatif yang lebih kuat dalam meyakinkan kesuksesan mereka oleh ketetapan hati mereka sendiri.

Selanjutnya Lee, et.al (2009) berpendapat bahwa agar individu mampu membuat keputusan yang lebih baik dalam berhadapan dengan permasalahan setiap hari yang tidak rutin, maka diperlukan keterampilan metakognisi. Dapat disimpulkan bahwa metakognisi mempengaruhi kemampuan peserta didik dalam membuat keputusan. Peserta didik merencanakan pemecahan masalah, mengontrol upaya yang dilakukan dalam memecahkan masalah, serta mengevaluasi apakah upaya dalam memecahkan masalah itu efektif. Smith (2013) mengungkapkan bahwa peserta didik dalam konteks tertentu yang memiliki kesadaran secara metakognitif menunjukkan performa akademik yang lebih baik. Peserta didik yang dapat memanajemen metakognisi, mampu menunjukkan performa yang lebih optimal.

\section{SIMPULAN DAN SARAN}

Sesuai dengan tema dan sub-tema yang dipetakan dalam kerangka keterampilan metakognisi mahasiswa terhadap mata kuliah statistik dapat disimpulkan bahwa: 1) Keterampilan metakognisi antara mahasiswa sangat beragam. Beberapa mahasiswa memiliki keterampilan metakognisi yang cenderung negatif dan beberapa mahasiswa juga memiliki keterampilan metakognisi yang cenderung positif; dan 2) Keterampilan metakognisi terhadap mata kuliah statistik dipengaruhi oleh beberapa faktor antara lain pengalaman ketika di Sekolah Dasar, Sekolah Menengah maupun telah memasuki semester awal perkuliahan di Perguruan Tinggi. Sebagai tambahan, guru dan/atau dosen yang mengajar statistik dikenal menakutkan dan memberikan instruksi yang sulit dipahami mahasiswa. Selain pengalaman di masa lalu dan faktor pengajar, keterampilan metakognisi terhadap mata kuliah statistik juga dipengaruhi oleh pendapat orang lain yang pada umumnya memandang bahwa statistik merupakan sesuatu yang rumit dan sulit.

Keterampilan metakognisi dapat mempengaruhi perilaku individu. Oleh karenanya hendaknya mahasiswa memiliki keterampilan metakognisi terhadap mata kuliah statistik secara positif.

\section{DAFTAR RUJUKAN}

Anderson, Neil J. (2002). The Role of Metacognition in Second Language Teaching and Learning. Washington: ERIC.

Arslan, S. \& Akin, A. (2014). Metacognition As a Predictor of One's Academic Locus of 
Control. Educational Science: Theory \& Practice, 14 (1): 33-39.

Bednarik, Kaisa.P. \& Keinonen, Tuula. (2011). Sixth graders' understanding of their own learning: A case study in environmental education course. International Journal of Enviromental \& Science Education, 6 (1): 59-78.

Boeree, C. G. (2008). General Psychology: Psikologi Kepribadian, Persepsi, Kognisi, Emosi, \& Perilaku. Diterjemahkan oleh Helmi J. Fauzi. Jogjakarta: Prismasophie.

Concepcion, David W. (2004). Reading Philosophy with Background Knowledge and Metacognition. Teaching Philosophy, 27 (4): 351-368.

Creswell, J.W. (2012). Educational Research: Planning, Conducting, and Evaluating Quantitative and Qualitative Research fourth edition. Amerika Serikat: Pearson Education.

Darmiany. (2016). Self-regulated Learning Mahasiswa Pendidikan Guru Sekolah Dasar (PGSD) Tahun Pertama. Jurnal Psikologi Pendidikan dan Konseling, 2 (1): 72-83.

Educational Performance System Inc. (2005), (Online), (http://www.epsiusa.com/approach/metacognition.htm), diakses 12 September 2014.

Flavell, J.H. (1979). Metacognition and Cognitive Monitoring: A new Area of Cognitive Development Inquiry. American Psychologist, 34 (10). Doi: 10.1037/0003-066X.34.10.906.

Hall, C.W. \& Webster, R.E. (2008). Metacognitive and Affective Factors of College Students With and Without Learning Disabilities. Journal of Postsecondary Education and Disability, 21 (1): 32-41.

Hamman, L.A. \& Stevens, R.J. (1998). Metacognitive Awareness Assessment in Self-Regulated Learning and Performance Measures in an Introductory Educational Psychology Course. Reports-Research. Amerika: ERIC.

Hanurawan, F. (2012). Metode Penelitian Kualitatif dalam Ilmu Psikologi. Surabaya: Pusat Studi Peningkatan Kinerja Masyarakat LPPM Universitas Airlangga.
Hergenhahn, B.R. \& Olson, M.H. (2008). Theories of Learning. Diterjemahkan oleh Tri Wibowo. Jakarta: Kencana.

Isaacson, Randy M. \& Fujita, Frank. (2006). Metacognitive Knowledge Monitoring and Self-Regulated Learning: Academic Success and Reflections on Learning. Journal of the Scholarship of Teaching and Learning, 6 (1): 39-55.

Jayapraba. (2013). Metacognitive Instruction and Cooperative Learning-Strategies for Promoting Insightful Learning in Science. International Journal on New Trends in Education and Their Implication, 4 (1): 165-172.

Jones, R.N. (2003). Basic Counseling Skills: A Helper's Manual. London: Sage Publicatios.

Laskey, M. \& Hetzel, C. (2010). Self-regulated Learning, Metacognition, and Soft Skills: The $21^{\text {th }}$ Century Learner. Online Submission: 1-17.

Lee, Chee B., Teo, Timothy T., \& Bergin, David. (2009). Children's Use of Metacognition in Solving Everyday Problems: An Initial Study from an Asian Context. The Australian Educational Researcher, 36 (3): 89-102.

Leedy, P.D. \& Ormrod, J.E. (2005). Practical Research: Planning and Design 6th edition. Amerika Serikat: Pearson Education.

Maulana. (2008). Pendekatan Metakognitif sebagai Alternatif Pembelajaran Matematika untuk Meningkatkan Kemampuan Berpikir Kritis Mahasiswa PGSD. Jurnal Pendidikan Dasar, 1 (1): 18.

Mytkowicz, P., Goss, D., \& Steinberg, B. (2014). Assessing Metacognition as a Learning Outcome in a Postsecondary Strategic Learning Course. Journal of Postsecondary Education and Disability, 27 (1): 51-62.

Nasution, S. (1988). Metode Penelitian Naturalistik Kualitatif. Bandung: Tarsito.

Nasution. (2003). Metode Research. Jakarta: PT. Bumi Aksara.

Nordell, S.E. (2009). Learning How to Learn: A Model for Teaching Students Learning Strategies. Bioscene: Journal of College Biology Teaching, 35 (1): 35-42.

Pate, M.L. \& Miller, G. (2011). Effects of Regulatory Self-Questioning on 
Secondary-Level Students' ProblemSolving Performance. Journal of the Scholarship of Teaching and Learning, 52 (1): 72-84.

Scott \& Berman. (2013). Examining the Domain-Specificity of Metacognition Using Academic Domains and TaskSpecific Individual Differences. Australian Journal of Educational \& Developmental Psychology, 13 : 28-43.

Shanon, Steven V. (2008). Using Metacognitive Strategies and Learning Styles to Create Self-Diercted Learners. Institute for Learning Styles Journal, 1 (1): 14-28.

Smith, Mary J. (2013). An Exploration of Metacognition And its Effect on Mathematical Performance in Differential Equations. Journal of the Scholarship of Teaching and Learning, 13 (1): 100-111.

Wade, C. \& Tavris, C. (2007). Psikologi, edisi ke-9. Diterjemahkan oleh Benedictine Widyasinta dan Darma Juwono. Jakarta: Erlangga.

Wilkinson, R.Tyle. (2011). Increasing Counselor Self-Awareness: The Role of Cognitive Complexity and Metacognition in Counselor Training Programs. Alabama Counseling Association Journal, 37 (1): 24-32. 